\section{DNA Fingerprints in Sports of 'Red Delicious' Apples}

\author{
Hilde Nybom ${ }^{1}$ \\ Biology Department, Box 1137 Washington University, Saint Louis, \\ MO 63130
}

Additional index words. Mahs $\times$ domestica, somatic mutation, cultivar identification, M13 probe, minisatellite DNA, RFLP

Abstract. Hybridization of minisatellite DNA with an M13 probe yields DNA fingerprints that usually are highly cultivar-specific. However, 15 different sports of 'Red Delicious' apples (Malus $\times$ domestics Borkh.) exhibited almost identical fingerprints. The mutations determining the morphological differences between the sports could not be detected by the minisatellite probe. These hypervariable DNA sequences appear rather stable in apples, making them ideal for differentiating between cultivars derived through genetic recombination but probably not very useful for differentiating between vegetative sports.

The cultivated apple has a complex genetic background, and different cultivars can thus be expected to differ widely from one another. On the contrary, little or no genetic variation is expected within cultivars since they are clonally propagated. In the past decade, isozyme electrophoresis has been used successfully to characterize various apple cultivars. Closely related cultivars, however, are difficult, if not impossible, to distinguish with this method, usually requiring analysis of several enzyme systems (Bournival and Korban, 1987; Weeden and Lamb, 1985). Not surprisingly, sports of the same cultivar have identical isozyme patterns (Weeden and Lamb, 1985).

Recently, DNA fingerprints, originally described in humans (Jeffreys et al., 1985), have been' investigated in both wild and cultivated plants (Dallas, 1988; Nybom et al., 1989; Rogstad et al., 1988; Ryskov et al., 1988: Weising et al.. 1989: Woodson. 1989: Zimmerman et al., 1989). The fingerprints are obtained by digesting the plant DNA with

Received for publication 6 Nov. 1989. The help of Roy Rom in obtaining the material and the technical advice of Steven Rogstad is gratefully acknowledged. This study was made possible through a grant from the Swedish Natural Science Research Council. The cost of publishing this paper was defrayed in part by the payment of page charges. Under postal regulations, this paper therefore must be hereby marked advertisement solely to indicate this fact.

'Current address: Balsgård - Dept. of Horticultural Plant Breeding, Swedish University of Agricultural Sciences, Fjälkestadsvägen 123-1, S29194 Kristianstad, Sweden. a restriction enzyme and hybridizing to the resulting fragments a labeled DNA probe homologous to certain hypervariable minisatellite-like regions of the genome. These regions consist of a tandemly repeated core sequence with variable numbers of tandem repeats at different loci. Thus, a single genotype (i.e., an individual or clonally propagated cultivar) can yield a complex and from A DNA digested with Hind III. specific pattern of bands on an autoradiograph.

In several cultivated plants, such as apples, identification of sports is critical for patent protection. The present study was thus undertaken to determine whether different sports of 'Red Delicious' apples had distinct DNA fingerprints as revealed-by a DNA probe homologous to one set of hypervariable loci.

Young leaves were collected at the Univ. of Arkansas, Fayetteville, from one tree each of 12 'Red Delicious' sports-'Ace Spur', 'Bisbee', 'Cascade', 'Cascade Spur', 'Early Red One'-, 'Imperial Red', 'Oregon Spur', 'Red Chief', 'Red Spur', 'Starking FW Red', 'Top Red' and 'Wellspur'-and from two trees each (samples kept separate) of 'Red Prince', 'Spur Red Royal', and 'Sturdee Spur'. These sports differ from one another mainly in growth habit and in fruit color. The DNA was extracted according to a modified version of Saghai-Maroof et al. (1984; for details see Nybom and Schaal, 1990b) and $10-\mu \mathrm{g}$ aliquots were digested separately with the restriction enzymes Dra I and Rsa I, respectively. All samples except 'Cascade Spur' were used in the Rsa I analysis, whereas only one tree of each sport was analyzed with Dra I. Digested DNA was electrophoresed in $0.9 \%$ agarose gels. The gels were Southern blotted onto hybridization transfer

\title{
ABCDEFGHIJKLMNOPQRSTUV
}

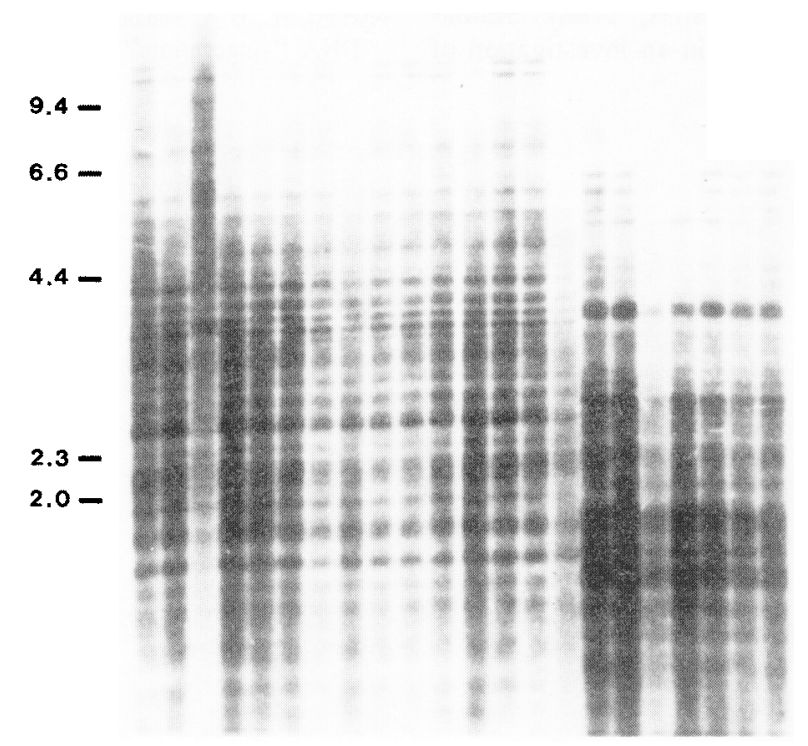

Fig. 1. DNA "fingerprints" of some 'Red Delicious' sports: A-O the entire" set of 15 different sports in alphabetical order, digested with Dra I; P-V 'Ace Spur', 'Bisbee', 'Wellspur', 'Early Red One', 'Imperial Red', 'Red Chief', and 'Starking FW Red' digested with Rsa I. Size markers were derived 
nylon (Nytran, Schleicher \& Schvell Inc., Keene, N.H.). Filters were hybridized with a probe derived from the M13 bacteriophage and hexamer-labeled with ${ }^{32} \mathrm{P}-\mathrm{dCTP}$ (Rogstad et al., 1988), and washed according to Westneat et al. (1988). Autoradiographs were made at $-80 \mathrm{C}$ for 5 to 10 days with intensifying screens.

Fragment patterns. With Dra I, at least 35 well-defined bands were visible, compared to 25 bands with $R s a$ I (Fig. 1). These bands were present for each sport, although relative intensity varied among sports. The mutations responsible for the morphological variation between sports seem not to have affected any of the loci to which the M13 probe hybridizes. However, most of these mutations probably affect single loci and are also in many cases chimaeral (Brown, 1975; Pratt, 1983), thus making them difficult to find. The sometimes rather large variation in band intensity seems to be of a quantitative nature and would not be useful for distinguishing these sports.

The overall homogeneity in banding patterns should be compared to the high levels of polymorphism found among 'Golden Delicious', 'Jonathan', 'Red Delicious', and 'Rome Beauty' (Nybom et al., 1990). In this earlier study, the probability of any two of these apple cultivars exhibiting identical patterns was $4.2 \times 10{ }^{-}$with Dra I and $1.4 \times$ $10^{-3}$ with $R s a$ I, as calculated according to the formula of Wetton et al. (1987).

Use of DNA fingerprints. DNA fingerprint analysis has been used to distinguish cultivars among apple, blackberry, and raspberry (Nybom et al., 1989, 1990). In paternity analyses of apple seedlings, progeny families of up to 24 plants were analyzed with DNA fingerprinting, and all seedlings exhibited individual-specific fingerprints (Nybom, 1990; Nybom and Schaal, 1990a). Rice cultivars, which are sexually propagated by selfpollination, show extensive variation between cultivars, whereas plants within a cultivar are identical (Dallas, 1988). Similar results were obtained in an investigation of flax cultivars, which are also self-pollinated (Zimmerman et al., 1989). In wild Rubus species with a clonal population structure, plants that presumably arose through sexual recombination exhibit individual-specific fingerprints, whereas plants most likely derived from vegetative propagation or apomictic seed production have identical fingerprints (Nybom and Schaal 1990b).

DNA fingerprinting appears to be a highly useful tool in distinguishing individual plants derived from sexual recombination in outcrossing, species or cultivars. However, plants derived through several generations of selfing or through vegetative propagation exhibit identical fingerprints and cannot be distinguished by use of minisatellite DNA analysis. Similarly, sports caused by one or a few mutations only will probably be rather difficult to distinguish with this method.

\section{Literature Cited}

Bournival, B.L. and S.S. Korban. 1987. Electrophoretic analysis of genetic variability in the apple. Scientia Hort. 31:233-243.

Brown, A.G. 1975. Apples, p. 3-37. In: J. Janick and J.N. Moore (eds. ). Advances in fruit breeding. Purdue Univ. Press, West Lafayette, Ind.

Dallas, J.F. 1988. Detection of DNA "fingerprints" of cultivated rice by hybridization with a human minisatellite probe. Proc. Natl. Acad. Sci. USA 85:6831-6835.

Jeffreys, A. J., V. Wilson, and S.L. Thein. 1985. Hypervariable 'minisatellite' regions in human DNA. Nature (London) 314:67-73.

Nybom, H. 1990. Genetic variation in ornamental apple trees and their seedlings (Malus, Rosaceae) revealed by DNA 'fingerprinting' with the M13 repeat probe. Hereditas. (In press.)

Nybom, H. and B.A. Schaal. 1990a. DNA "fingerprints" applied to paternity analysis in apples (Malus $\times$ domestica). Theor. Applied Genet. 79:763-768.

Nybom, H. and B.A. Schaal. 1990b. DNA "fingerprints" reveal genotypic distributions in natural populations of blackberries and raspberries (Rubus L., Rosaceae). Amer. J. Bet. 77:883888 .

Nybom, H., B.A. Schaal, and S.H. Rogstad. 1989. DNA "fingerprints" can distinguish cultivars of blackberries and raspberries. Acta Hort. 262:305-310.

Nybom, H., S.H. Rogstad, and B.A. Schaal. 1990. Genetic variation detected by use of the M13 "DNA fingerprint" probe in Malus, Prunus, and Rubus (Rosaceae). Theor. Applied Genet. 79:153-156.

Pratt, C. 1983. Somatic selection and chimeras, p. 172-186. In: J.N. Moore and J. Janick (eds.). Methods in fruit breeding. Purdue Univ. Press, West Lafayette, [rid.

Rogstad, S. H., J.C. Patton II, and B.A. Schaal. 1988. M13 repeat probe detects DNA minisateliite-like sequences in gymnosperm and angiosperms. Proc. Natl. Acad. Sci. USA 85:91769178.

Ryskov, A. P., A.G. Jincharadze, M.I. Prosnyak, P.L. Ivanov, and S.A. Limborska. 1988. M13 phage DNA as a universal marker for DNA fingerprinting of animals, plants and microorganisms. FEBS Let. 233:388-392.

Saghai-Maroof, M. A., K.M. Soliman, R.A. Jorgensen, and R.W. Allard. 1984. Ribosomal DNA spacer-length polymorphism in barley: Mendelian inheritance, chromosomal location, and population dynamics. Proc. Natl. Acad. Sci. USA 81:8014-8018.

Weeden, N.F. and R.C. Lamb. 1985. Identification of apple cultivars by isozyrne phenotypes. J. Amer. Soc. Hort. Sci. 110:509-515.

Weising, K., F. Weigand, A.J. Driesel, G. Kahl, H. Zischler, and J.T. Epplen. 1989. Polymorphic simple GATA/GACA repeats in plant genomes. Nucleic Acids Res. 17:10128.

Westneat, D. F., W.A. Noon, H.K. Reeve, and C.F. Aquadro. 1988. Improved hybridization conditions for DNA 'fingerprints' probed with M13. Nucleic Acids Res. 16:4161.

Wetton, J. H., R.E. Carter, D.T. Parkin, and D. Walters. 1987. Demographic study of a wild house sparrow population by DNA fingerprinting. Nature (London) 327:147-149.

Woodson, W.R. 1989. DNA fingerprinting for cultivar identification in carnation. 86th Annu. Meeting of the Amer. Soc. Hort. Sci., Tulsa, Okla. O (suppl.): 110.

Zimmerman, P. A., N. Lang-Unnasch, and C.A. Cullis. 1989. Polymorphic regions in plant genomes detected by an M13 probe. Genome $32: 826-828$ 